\title{
Phenolic, flavonoid and anthocyanin contents of local sweet potato (Ipomoea batatas)
}

\author{
${ }^{1}$ Shaari, N., ${ }^{1,2 *}$ Shamsudin, R., ${ }^{1}$ Mohd Nor, M.Z. and ${ }^{3}$ Hashim, N. \\ ${ }^{1}$ Department of Process and Food Engineering, Faculty of Engineering, Universiti Putra Malaysia, 43400 \\ UPM Serdang, Selangor, Malaysia. \\ ${ }^{2}$ Halal Products Research Institute, Universiti Putra Malaysia, 43400 Serdang, Selangor, Malaysia. \\ ${ }^{3}$ Department of Agriculture and Biology, Faculty of Engineering, Univerisiti Putra Malaysia, 43400 UPM \\ Serdang, Selangor, Malaysia
}

\section{Article history: \\ Received: 3 July 2019 \\ Received in revised form: 2 \\ October 2019 \\ Accepted: 10 October 2019 \\ Available Online: 10 \\ February 2020}

\section{Keywords:}

Sweet potato,

Peeled,

Unpeeled,

Total phenolic content,

Flavonoid content,

Anthocyanin

DOI:

https://doi.org/10.26656/fr.2017.4(S1).S01

\begin{abstract}
The sweet potato (Ipomoea batatas) is an annual herb of the family Convolvulaceae and ranked as the world's seventh most important food crop with a major contribution to energy and phytochemical source of nutrition. Three different conditions of sweet potatoes are unpeeled tuber (UPSP), peeled tuber (PSP) and skin of tuber (SSP). The objective of this study is to evaluate the phytochemical availability (total phenolic contents (TPC), total flavonoid contents (TFC) and anthocyanin content) in the different parts of the sweet potato tuber. Folin-Ciocalteau (FC) assay showed that phenolic contents for UPSP (41.14 $\pm 1.69 \mathrm{mg}$ GAE/100 g dry basis) and PSP (42.24 $\pm 2.19 \mathrm{mg}$ GAE/100 g dry basis) were significantly (50\%) higher than SSP $(26.01 \pm 2.04 \mathrm{mg}$ GAE/100 g dry basis). In terms of flavonoid content, the highest value was retained in PSP $(9.55 \pm 0.82 \mathrm{mg}$ quercetin/100 g dry basis) followed by UPSP ( $3.30 \pm 0.19 \mathrm{mg}$ quercetin/100 g dry basis) and SSP (1.43 \pm $0.03 \mathrm{mg}$ quercetin/100 g dry basis). PSP $(9.43 \pm 0.08 \mathrm{mg} / 100$ dry basis) had a higher anthocyanin content compared to UPSP $(5.21 \pm 0.02 \mathrm{~b} \mathrm{mg} / 100 \mathrm{~g}$ dry basis) and SSP $(5.21 \pm 0.02 \mathrm{~b} \mathrm{mg} / 100 \mathrm{~g}$ dry basis). The phytochemical properties were available in all conditions of the sweet potato. However, PSP was suggested to be the most preferable condition for further processing in the sweet potato industry.
\end{abstract}

\section{Introduction}

The sweet potato or 'Ubi Keledek' (Ipomoea batatas) is a staple food throughout the world. The sweet potato is well-known globally because of its desirable properties. The shape of the sweet potato can be in fusiform globular, round or ovate with a smooth, ridged or rough surface. The skin colour varies from white to yellow, orange, red, purple or brown while the flesh may be white, yellow, orange, reddish or purple (Lebot, 2009). Its weight ranges from 150 to $250 \mathrm{~g}$ as described by Rosnani et al. (2017). The sweet potato has a significant supply in terms of energy supplement and as a phytochemical source of nutrition (Shekhar et al., 2015). The nutrients in sweet potatoes help in preventing cardiovascular diseases and act as anti-carcinogens (Teow et al., 2007). According to Woolfe (1993), the most abundant compounds in the sweet potato are minerals, vitamins, dietary fibre, and antioxidants such as phenolic acids, anthocyanins, tocopherol and betacarotene. The phenolic contents and total flavonoids of sweet potato range from $10.13-80.78 \mathrm{mg}$ GAE per 100 $\mathrm{g}$ and $22.02-35.47 \mathrm{mg}$ quercetin per $100 \mathrm{~g}$, dry matter respectively (Huang et al., 2005). Huang et al. (2005) also reported that the content of anthocyanin ranges from 0.36 - $8.99 \mathrm{mg}$ per $100 \mathrm{~g}$, dry matter.

The nutritional values of crop species need to be improved to fulfil the human desire for the maintenance of optimal health. Accordingly, global scientific research is targeted at gathering knowledge of the nutritional qualities of food crops and improving their values. A lack of information in recognising the possible nutritional values of sweet potato waste will result in its underutilisation. The information available on the nutritional value of this species of sweet potato is limited and fragmented. Knowledge of the nutritional content of this cultivar and its waste will affect the way it is consumed and reduce the wastage of sweet potato. Hence, it is essential to exploit the nutrients available in the sweet potato to improve its nutritional implications. Subsequently, this study aims to evaluate the phytochemical availability (total phenolic contents (TPC), total flavonoid contents (TFC) and anthocyanin 
content) in the different parts of the sweet potato tuber.

\section{Materials and methods}

\subsection{Preparation of sample}

The method of sample preparation followed the method by Nurfarhana et al. (2019). In brief, sweet potatoes (Ipomoea batatas) of the Anggun 1 variety were obtained from a farm in Semenyih, Selangor. Variability was controlled by selecting sweet potatoes from the same variety known as Anggun 1. The whole tuber was cleaned and divided into three parts; unpeeled tuber, peeled tuber and skin of tuber as shown in Figure 1. All the parts were sliced thinly at $5 \mathrm{~mm}$ thickness and ovendried at $60^{\circ} \mathrm{C}$ for $24 \mathrm{hrs}$. The dried samples were ground and sifted to pass through a $250 \mu \mathrm{m}$ sieve. The sweet potato powder was kept in an airtight container at $4^{\circ} \mathrm{C}$ for further analysis.

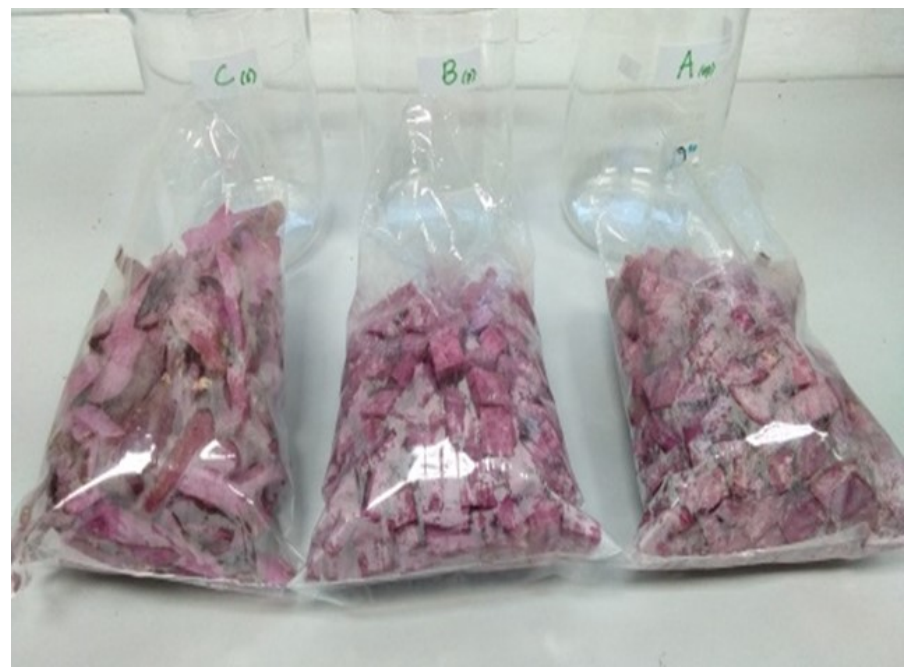

Figure 1. SSP (Left), UPSP (Middle) and PSP (Right)

\subsection{Preparation of Anggun 1 extracts}

Sweet potato powders from the three different parts were extracted according to the method of Huang et al. (2005). About $1 \mathrm{~g}$ of each sample was treated with $80 \%$ methanol $(15 \mathrm{~mL})$ and centrifuged at $1600 \times \mathrm{x}$ for 15 mins. The suspension was re-extracted using another 10 $\mathrm{mL}$ of $80 \%$ methanol as before. The supernatant was combined and filtered through Whatman No. 4 filter paper and diluted to $25 \mathrm{~mL}$. The extract was stored at $4^{\circ} \mathrm{C}$ for further analysis.

\subsection{Determination of phytochemical properties}

\subsubsection{Total phenolic content}

Total phenolic content was determined using FolinCiocalteau (FC) assay (Huang et al., 2005). The aliquot of extract $0.2 \mathrm{~mL}$ was treated using $1.0 \mathrm{~mL}$ of FolinCiocalteau's reagent and $0.8 \mathrm{~mL}$ of $7.5 \%$ saturated sodium carbonate solution. After being homogenised using a vortex, the mixture was kept for 30 mins at room temperature. Then, the absorbance was measured versus a blank at $765 \mathrm{~nm}$ in a spectrophotometer. The results were expressed as gallic acid equivalent (mg GAE/100 g dry matter) using a gallic acid standard calibration curve. The results were evaluated in triplicate.

\subsubsection{Flavonoid content}

The spectrophotometric method based on aluminium chloride $\left(\mathrm{AlCl}_{3}\right)$ complexation was used to determine the content of flavonoid according to previously described steps by Huang et al. (2005). An aliquot $(0.5 \mathrm{~mL})$ from the extract of the sample in methanol was treated with $1.0 \mathrm{~mL}$ of $2 \%$ methanolic Aluminium Chloride $\left(\mathrm{AlCl}_{3}\right.$. $6 \mathrm{H}_{2} \mathrm{O}$ ) and homogeneously mixed using a vortex. After 10 mins, the absorbance was read using a spectrophotometer at $430 \mathrm{~nm}$ versus blank. The samples were analysed and calculated using a calibration curve of quercetin for quantification. The results were expressed as $\mathrm{mg}$ quercetin/100 $\mathrm{g}$ dry matter.

\subsubsection{Anthocyanin}

The content of anthocyanin was determined according to Huang et al. (2005). The sample $(0.5 \mathrm{~g})$ was extracted with $10 \mathrm{~mL}$ of acidified methanol $(1 \%$ Hydrochloric Acid $(\mathrm{HCl}))$ and centrifuged at $1600 \times \mathrm{x}$ for 15 mins. The suspension was re-extracted using an additional $10 \mathrm{~mL}$ of acidified methanol. All the supernatant was collected and diluted to $25 \mathrm{~mL}$. The absorbance was measured at $530 \mathrm{~nm}$. The anthocyanin content was determined using the equation below:

Anthocyanin content $(\mathrm{mg} / 100 \mathrm{~g}$ of dry matter $)=\mathrm{A} \times$ $\mathrm{MW} \times \mathrm{DF} \times 100 /(\varepsilon \times \mathrm{W})$

Where $\mathrm{A}=$ absorbance; $\mathrm{MW}=$ molecular weight of cyanidin-3-glucoside chloride $\left(\mathrm{C}_{21} \mathrm{H}_{21} \mathrm{C}_{1} \mathrm{O}_{11}, 484.84 \mathrm{Da}\right)$; $\mathrm{DF}=$ dilution factor; $\varepsilon=$ molar absorptivity $(34,300)$; and $\mathrm{W}=$ sample weight $(\mathrm{g})$.

\subsection{Statistical analysis}

The data collected were analysed using SPSS Statistics 22.0 Edition. One-way Analysis of Variance (ANOVA) and Duncan's Test was used to evaluate the significant difference between mean values. The significant difference was measured at a confidence level of $95 \%(p<0.05)$. Each analysis was done and analysed in triplicate.

\section{Results and discussion}

\subsection{Phytochemical properties}

The total phenolic content (TPC) of Anggun 1 for different treatments were expressed as $\mathrm{mg}$ GAE/100 g sample and are shown in Table 1 . The phenolic content for each analysed sample in the study was observed for UPSP (41.14 $\pm 1.69 \mathrm{mg}$ GAE/100 g dry basis), PSP 
Table 1. Phytochemical properties of different parts of sweet potato powders

\begin{tabular}{|c|c|c|c|}
\hline $\begin{array}{l}\text { Sample/ } \\
\text { treatment }\end{array}$ & $\begin{array}{c}\text { Total phenolic content } \\
\text { (mg GAE } 100^{-1} \text {, Dry Basis) }\end{array}$ & $\begin{array}{l}\text { Total flavonoid content (mg } \\
\text { quercetin } 100^{-1} \text {, Dry Basis) }\end{array}$ & $\begin{array}{c}\text { Anthocyanin } \\
\text { (mg } 100^{-1} \text {, Dry Basis) }\end{array}$ \\
\hline UPSP $^{1}$ & $41.14 \pm 1.69^{\mathrm{a}}$ & $3.30 \pm 0.19^{b}$ & $5.21 \pm 0.03^{b}$ \\
\hline $\mathrm{PSP}^{2}$ & $42.24 \pm 2.19^{\mathrm{a}}$ & $9.55 \pm 0.82^{\mathrm{a}}$ & $9.43 \pm 0.08^{\mathrm{a}}$ \\
\hline $\mathrm{SSP}^{3}$ & $26.01 \pm 2.04^{\mathrm{b}}$ & $1.43 \pm 0.03^{c}$ & $5.21 \pm 0.02^{b}$ \\
\hline
\end{tabular}

Results were expressed as mean \pm standard deviation $(n=3)$. Different superscripts in each column indicate significant difference $(\mathrm{p}<0.05)$. All data expressed in dry weight basis. ${ }^{1}$ UPSP: Powder from unpeeled sweet potato. ${ }^{2}$ PSP: Powder from peeled sweet potato. ${ }^{3} \mathrm{SSP}$ : Powder from the skin of the sweet potato

$(42.24 \pm 2.19 \mathrm{mg}$ GAE/100 g dry basis) and SSP (26.01 $\pm 2.04 \mathrm{mg}$ GAE/100 g dry basis). The TPC for UPSP and PSP were observed to be $50 \%$ significantly higher $(p>0.05)$ than SSP. This might be due to the accumulation of phenolic compounds in the flesh of the sweet potato. The data obtained for UPSP, PSP and SPP were consistent with previous studies by Huang et al. (2005), which was 10.13 - $80.78 \mathrm{mg}$ GAE/100 g dry basis and Teow et al. (2007) at $0.1-42.2 \mathrm{mg} \mathrm{GAE} / 100 \mathrm{~g}$ dry basis. However, the study by Ahmed et al. (2010) reported a contrastingly lower value for the TPC of unpeeled and peeled sweet potato $(4.29-8.33 \mathrm{mg} / 100 \mathrm{~g}$ dry basis). The various conditions and type of sweet potato may have contributed to this difference. Ahmed et al. (2010) dried the samples at different temperatures $\left(55,60\right.$ and $\left.65^{\circ} \mathrm{C}\right)$ for $7-8 \mathrm{hrs}$ prior to analysis while Huang et al. (2005) did not. Furthermore, there was no significant difference observed between UPSP and PSP (Table 1). This finding is in line with a previous study reported by Truong et al. (2007). These results indicate that there is no beneficial effect in terms of phenolic content in using unpeeled tuber for product processing.

Table 1 shows that the flavonoid content is significantly highest $(\mathrm{p}>0.05)$ in PSP at $9.55 \pm 0.82 \mathrm{mg}$ quercetin/100 $\mathrm{g}$ dry basis, followed by UPSP $(3.30 \pm 0.19$ $\mathrm{mg}$ quercetin/100 g dry basis) and SSP (1.43 $\pm 0.03 \mathrm{mg}$ quercetin/100 g dry basis). This data correlates with the high TPC in PSP. It has been observed that a high TPC reflects a high flavonoid content. In comparison, the flavonoid contents of UPSP, PSP and SSP were much higher than the potato $(0.13 \mathrm{mg} / \mathrm{kg}$ fresh weight) (Chu et al., 2000). The flavonoid contents in apples (26.4- 73.9 $\mu \mathrm{g} / \mathrm{g}$ of fresh weight) (Price et al., 1999) and blueberries and blackberries $(21-390 \mathrm{mg} / 100 \mathrm{~g}$ of fresh weight) (Sellappan et al., 2002) were observed to be much higher compared than in UPSP, PSP and SSP. The flavonoid content of SSP reported in the present study is lower than the potato peel reported by Mendel Friedman et al. (2017).

Anthocyanins are an essential group of flavonoid compounds that result in various flesh colours (Wang et al., 2018). Kahkonen et al. (2003) stated that edible plants with purple, red or blue colours form the most essential sources of anthocyanins. Among the analysed three conditions of Anggun tuber, PSP showed the significantly richest $(\mathrm{p}>0.05)$ content of anthocyanins $(9.43 \pm 0.08 \mathrm{mg} / 100 \mathrm{~g}$ dry basis), followed by UPSP $(5.21 \pm 0.02 \mathrm{~b} \mathrm{mg} / 100 \mathrm{~g}$ dry basis) and SSP $(5.21 \pm 0.02 \mathrm{~b}$ $\mathrm{mg} / 100$ dry basis). There was no significant difference between UPSP and SSP. The major components in purple and red-fleshed sweet potatoes with high anthocyanins are peonidin and cyanidin as reported by several investigators (Furuta et al., 1998; Oki et al., 2002; Suda et al., 2003; Harada et al., 2004). The anthocyanin content of PSP is comparable with the anthocyanin content of red and purple fruits and vegetables ( 0.02 to $6 \mathrm{mg}$ anthocyanins/fresh weight) (Wrolstad, 2000).

\section{Conclusion}

The phenolic, flavonoid and anthocyanin contents of three different conditions (UPSP, PSP and SSP) of Anggun 1 were investigated. The results showed the effect of different parts on the total phenolic content, flavonoid content and anthocyanin content. Sweet potato flour enhances the quality of food products from the aspects of colour, flavour, natural sweetness and supplemented nutrients. Therefore, flour from PSP is suggested to produce better quality products which are more appealing to product developers and consumers.

\section{Conflict of Interest}

The authors claim no conflict of interest.

\section{Acknowledgments}

The authors express their gratitude to the Universiti Putra Malaysia for providing financial and technical support under grant GP-IPB/2018/9660301 to conduct this research work.

\section{References}

Ahmed, M., Akter, M.S. and Eun, J.-B. (2010). Peeling, drying temperatures, and sulphite-treatment affect physicochemical properties and nutritional quality of sweet potato flour. Food Chemistry, 121(1), 112118. https://doi.org/10.1016/j.foodchem.2009.12.015

Chu, Y.-H., Chang, C.-L. and Hsu, H.-F. (2000). 
Flavonoid content of several vegetables and their antioxidant activity. Journal of the Science of Food and Agriculture, 80(5), 561-566. https:// doi.org/10.1002/(SICI)1097-0010(200004) 80:5<561::AID-JSFA574>3.0.CO;2-\%23

Furuta, S., Suda, I., Nishiba, Y. and Yamakawa, O. (1998). High tertbutylperoxyl radical scavenging activities of sweet potato cultivars with purple flesh. Food Science and Technology International of Tokyo, 4(1), 33-35. https://doi.org/10.3136/ fsti9596t9798.4.33

Harada, K., Kano, M., Takayanagi, T., Yamakawa, O. and Ishikawa, F. (2004). Absorption of acylated anthocyanins in rats and humans after ingesting an extract of Ipomoea batatas purple sweet potato tuber. Bioscience Biotechnology and Biochemistry, 68(7), 1500-1507. https://doi.org/10.1271/ bbb. 68.1500

Huang, Y.C., Chang, Y.H. and Shao, Y.Y. (2005). Effects of genotype and treatment on the antioxidant activity of sweet potato in Taiwan. Food Chemistry, 98(3), 529-538. https://doi.org/10.1016/ j.foodchem.2005.05.083

Kahkonen, M. P., Heinamaki, J., Ollilainen, V. and Heinonen, M. (2003). Berry anthocyanins: isolation, identification and antioxidant activities. Journal of the Science of Food and Agriculture, 83(14), 1403e1411. https://doi.org/10.1002/jsfa.1511

Lebot, V. (2009). Tropical root and tuber crops Cassava, Sweet Potato, Yams and Aroids. UK: MPG Books Group.

Nurfarhana, S., Rosnah, S., Mohd. Zuhair, M.N., Norhashila, H. and Azman, H. (2019). Effect of Storage Duration on The Colour Value of Sweet Potatoes (Ipomoea batatas). International Food and Agriculture Engineering Conference 2019, Putrajaya. Malaysia: Malaysian Society of Agricultural Engineers

Oki, T., Masuda, M., Furuta, S., Nishiba, Y., Terahara, N. and Suda, I. (2002). Involvement of anthocyanins and other phenolic compounds in radical scavenging activity of purple-fleshed sweet potato cultivars. Journal of Food Science, 67(5), 1752-1756. https:// doi.org/10.1111/j.1365-2621.2002.tb08718.x

Rosnani, A.G., Anuar, A., Hairuddin, M.A., Md. Akhir, H., Mohd, Nazri, B., Nur Izalin, M.Z., Nurul Afza, K., Rosalizan, M.S., Thiyagu, D. and Wan Khairul, A.W.A. (2017). Manual Teknologi Pengeluaran Ubi Keledek Ungu Anggun. Malaysia: MARDI

Sellappan, S., Akoh, C.C. and Krewer, G. (2002). Phenolic compounds and antioxidant capacity of Georgia-grown blueberries and blackberries. Journal of Agricultural and Food Chemistry, 50, 2432-2438. https://doi.org/10.1021/jf011097r

Shekhar, S., Mishra, D., Buragohain, A.K., Chakraborty, S. and Chakraborty, N. (2015). Comparative analysis of phytochemicals and nutrient availability in two contrasting cultivars of sweet potato (Ipomoea batatas L.). Food Chemistry, 173, 957 - 965. https:// doi.org/10.1016/j.foodchem.2014.09.172

Suda, I., Oki, T., Masuda, M., Kobayashi, M., Nishiba, Y. and Furuta, S. (2003). Physiological functionality of purple-fleshed sweet potatoes containing anthocyanins and their utilization in foods. Japan Agricultural Research Quarterly, 37(3), 167-173. https://doi.org/10.6090/jarq.37.167

Teow, C.C., Truong, V.D., McFeeters, R.F., Thompson, R.L., Pecota, K.V. and Yencho, G.C. (2007). Antioxidant activities, phenolic and b-carotene contents of sweet potato genotypes with varying flesh colours. Food Chemistry, 103(3), 829-838. https://doi.org/10.1016/j.foodchem.2006.09.033

Truong, V.D., McFeeters, R.F., Thompson, R.T., Dean, L.L. and Shofran, B. (2007). Phenolic Acid Content and Composition in Leaves and Roots of Common Commercial Sweetpotato (Ipomea batatas L.) in the United States. Food Chemistry and Toxicology, 72, 343-349. https://doi.org/10.1111/j.17503841.2007.00415.x

Wang, A., Li, R., Ren, 1., Gao, X., Zhang, Y., Ma, Z., Ma, D. and Luo, Y. (2018). A comparative metabolomics study of flavonoids in sweet potato with different flesh colors (Ipomoea batatas (L.) Lam). Food Chemistry, 260, 124-134. https:// doi.org/10.1016/j.foodchem.2018.03.125

Wrolstad, R.E. (2000). Anthocyanins. In Lauro, G.J. and Francis, F.J. (Eds.). Natural food colorants, p. 237252. New York: Marcel Dekker. 